\title{
RESHAPING WATERS. A HISTORY OF POLITICAL INTERFERENCE IN THE RISE AND FALL OF THE ROMANIAN SPA-TOWNS - CASE STUDY: SÂNGEORZ-BĂI
}

\author{
SILVIU-CLAUDIU BORȘ ${ }^{1}$
}

\begin{abstract}
Reshaping Waters. A History of Political Interference in the Rise and Fall of the Romanian Spa-Towns - Case Study: Sângeorz-Băi. A curious case in Romania's architectural narrative is represented by its spatowns, many of which have had seemingly regrettable fates. Once the crown jewels of the country's tourism segment, only a few of this type of urban developments have retained their prestige, many of them being mere shadows of what they once were. Sângeorz-Băi, a small town in the northern county of Bistrița-Năsăud, falls somewhere in-between these two categories. By definition, spa-towns are resort towns developed on mineral springs that have appeared naturally and have been preserved for their health benefits. Seeing as the spatown archetype is based on a commodity meant to be enjoyed by people, the interference of politics in the evolution of this type of urban entities came naturally. The proposed article means to explore how political interference affected the evolution of the aforementioned towns, Sângeorz-Băi being used as a case study that mirrors the ways in which political actors have affected the whole array of Romanian spa-towns. The entire intended discourse's foundation would be based on reviewing the perks and misadventures that this type of towns have encountered through their existence, aspects that will be documented through archive studies, historical research and personal experience - the author of the intended article being a native of the spa-town Sângeorz-Băi, and also, in a way, a political actor himself, struggling to preserve some of the last historical buildings that the local authorities have yet to demolish (Fig.1).
\end{abstract}

Keywords: spa-town; heritage; mineral waters; villa; balneotherapy, sojourn; tourism.

\footnotetext{
1 Ph.D. Student at the Technical University of Cluj-Napoca, Teaching Assistant at the Faculty of Architecture and Urban Planning, Email: Silviu.Bors@arch.utcluj.ro. This paper is part of the author's research within his Ph.D. thesis.
} 


\section{Preface}

„My dear, I'm letting you know that I have demolished your precious villa. I know you were in the process of classifying it as a monument, but I do not care, it was ruined, and it was falling on children. I took it down, it is over." 2

"The person to be named mayor of a spa town will be needed to possess an academic title."3

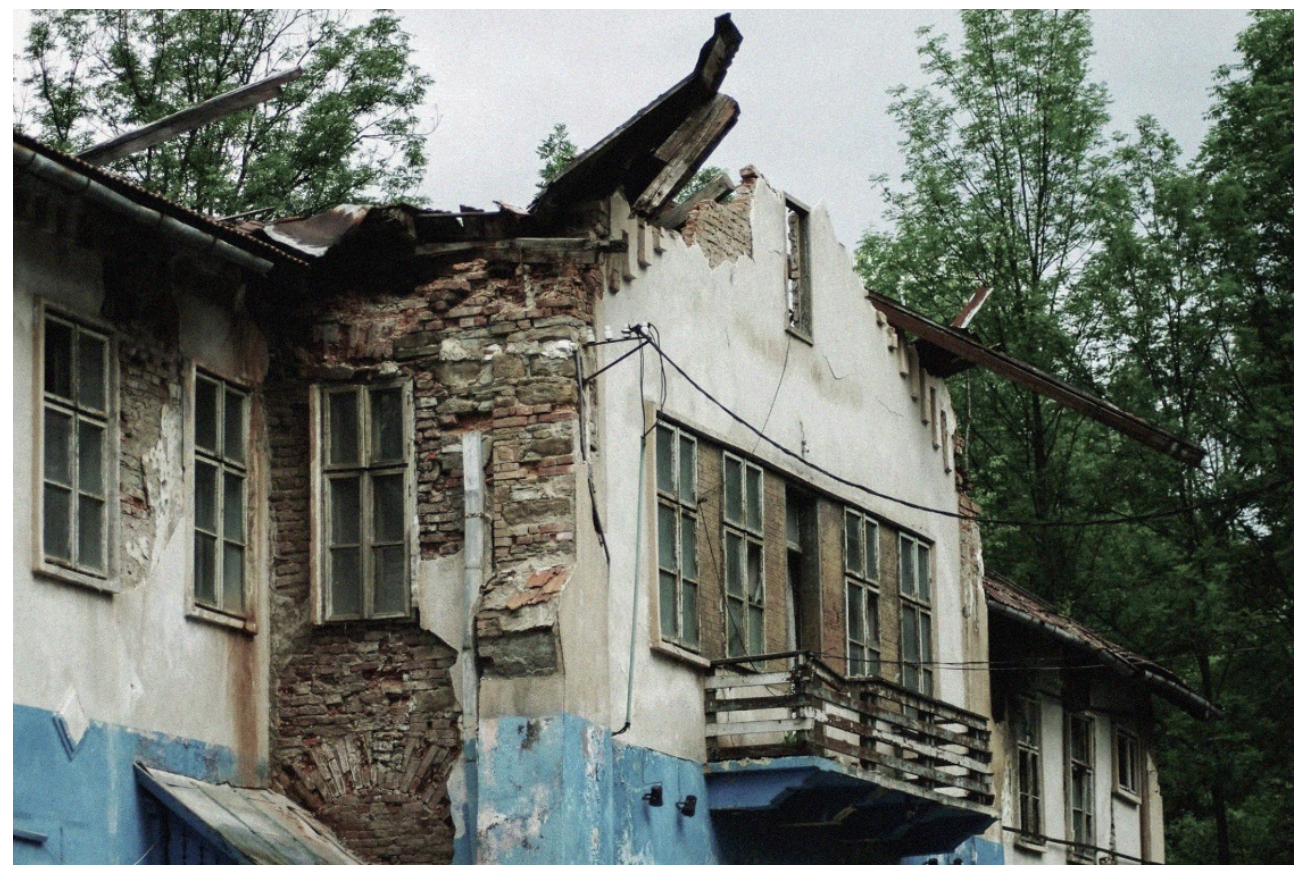

Fig. 1. - Vila 13, or The Old Hebe Hotel, prior to its demolition in 2018. Source: author.

\footnotetext{
2 Extract from a telephone call received by the author of this paper from the mayor of spa-town Sângeorz-Băi, on April 19 2018, one day after the demolition of one of the last building standing from the town's historical existence, Villa 13, [“- Dragule, te sun ca să te anunt că țiam demolat vila frumoasă. Știu că ai încercat să o clasezi monument, nu mă interesează, stătea distrusă aici și pica pe copii. Am dat-o jos, e gata."]

${ }^{3}$ Extract from The Law No.569 from the 26 of March 1936, Article 111, Paragraph 1 [Primarul numit în comunele declarate stațiuni balneare sau climatice va trebui să poseadă un titlu academic.]
} 
RESHAPING WATERS. A HISTORY OF POLITICAL INTERFERENCE IN THE RISE AND FALL OF THE ...

\section{Foreword}

A curious case in Romania's architectural narrative is represented by its spa-towns, many of which have had seemingly regrettable fates. Once the crown jewels of the country's touristic segment, only a few of this type of urban developments have retained their prestige, many of them being mere shadows of what once was. Sângeorz-Băi, a small town in the northern county of Bistrița-Năsăud, falls somewhere in-between these two categories.

The main reason behind choosing Sângeorz-Băi as the main pillar of this study resides in the fact that the author of the article is a native of the aforementioned spa-town and also, in a way, a political actor himself, struggling to preserve some of the last historical buildings that the local authorities have yet to demolish. We say yet to demolish because very recently, in the beginning of April 2018, the mayor and the city council have decided to take down one of the last standing villas that were part of the historical spa-town, citing public safety as the main reason behind the decision. The conundrum is far from simple; years of poor administration and lack of interest towards the historical value of the remaining architectural entities surely paved the way towards the regrettable fate, but was the cleansing decision the best one? Sadly, in a subject already crippled by the passing of time, only more time will tell.

As a PhD student, I started my thesis - which tackles the evolution of Sângeorz-Băi, purely on an affective basis. Seeing the current state of the town, a landscape composed of a few nearly destroyed historical buildings and two empty hotels from the socialist period ignited a personal need to act, my desired intervention being comprised of a thorough research of the establishment's past that could afterwards generate a series of strategies that could possibly help the spa-town's future. I have begun my studies in the field of spa-towns with small and sincere ideas. Through temperate episodes of reverie, I imagined that the conclusions to my studies would lead to some changes in the perception of the subject, or that maybe, with some chance, they would influence some attitudes. I was sure that the road would not be easy, but never would I have imagined that my good intentions would be so strongly held back by the people who should be the most entitled to help - those chosen to represent and defend the values of the town. I say these words not only in the light of the recent demolition, but also in view of the general attitude that the local administration has towards heritage, perceiving the old structures as mere impediments in their quest for immediate financial gain. The poor understanding of the importance possessed by the historical buildings combined with a series of shallow strategies - like the proposal of a new luxurious hotel in a forgotten city that already has 1500 empty hotel rooms - are proving to be a dangerous combination for what is left of the once flourishing spa-town. 
Therefore, it is imperative that a consensus must be reached regarding the importance of the town's heritage. I have personally tried to convince members of the local administration to establish procedures regarding monument classifications, as to make some of the remaining historical buildings eligible to large refurbishment investments - only to be hit with negative responses, whilst taking matters into my own hands proved to be belated. Nonetheless, the demise of Vila 13 will not mark the end of my efforts, as I perceive the unfortunate event as an incentive to a new and better determined procedure of classification - one involving the area of the entire park of the spa-town. ${ }^{4}$ In the meantime my highest priority will be to enhance the local community's scope of understanding regarding its past values.

All things considered, this paper is by no means a pointed finger towards a sole culprit concerning the current state of the establishment, but more of a clenched fist held under the chin, in a contemplating position - a meditation session on what was - and what is. A look towards what it has become must, however, be preceded by a study on how it came to be.

\section{A search for beauty}

The beginnings of small Romanian villages tend to be sometimes romanticized, either for the sake of seeking a glorious past, or for the need to differentiate and elevate a certain town and its inhabitants from the neighbouring settlements. Sângeorz-Băi is not an exception to this behaviour, with myths and legends passed through stories from the elders, that place the first inhabitants of the old town in the realm of the unbent Dacians that did not surrender to the Romans and retreated in the northern forests of Transylvania. Legends of ancient ancestors like the great hunter Dan and his acolytes, or remembrances of the Tartar invasion give the names of the surrounding natural elements (Sohorca, 1986).

Although the present paper's objective is by far not one of geographical purposes, one must first look at what made the idea of a spa-town appealing, the cornerstone of this type of urban development being the spectacle of the surroundings. Therefore, the development of this type of villages heavily relies on the entity of the tourist and that of nature. In the case of spa-towns, nature and its offerings become attractions. Dean MacCannell describes attractions as either "souvenirs" or "true sights" - souvenirs are attractions of small scale or importance, which attract individuals, while true sights are collected by entire societies (MacCannell, 1999, p. 42). It is clear that spa-towns fall in the category of

\footnotetext{
${ }^{4}$ All of the remaining buildings are either located in the park, or near its area. The public space in itself presents real historical value, being the nucleus of the old spa-town.
} 
the true sights, the whole idea of visiting these establishments and enjoying their facilities becoming a subject of almost ritualistic attitudes (MacCannel, 1999).

However, for this type of developments to flourish, a sense of ingenuity was necessary. The villages had to evoke an urban atmosphere, while still retaining their rural charm (Hajdu, 2012). The whole subject of the appearance of the Romanian spa-towns serves as a reflection of the process of modernization that the country desired, the cultural effort of synchronization with Europe being led by borrowing social practices (Hajdu, 2012). Romanian spa towns thus serve as an exponent of the pursuit of modernity and relevance that the country has led, roads that were preceded and incentivized first and foremost by one's constant need and search for beauty.

\section{A search for emergence}

The architecture and urban development behind the spa-town type of establishments comes as a response to a certain need of a social group, or class - in this case the search for health and leisure. As John Ruskin points out in his book "The seven lamps of architecture", this specific type of art field arranges itself under five heads: devotional, memorial, civil, military and domestic (Ruskin, 1849). Albeit certainly well rooted in the domestic, spatown architecture is definitely highly dependent of civil efforts. These particular types of architectural developments are derivative of the natural blessings of the surroundings, but without concentrated support from certain entities, the scenery becomes a mere unused canvas. Therefore, it is obvious that for this type of establishments to flourish, the implication and cooperation of people is imperative. In the case of Sângeorz-Băi, most of the catalysts behind its development were tangent to the political realm.

One of the first political entities to have an impact on the development of the case-study spa-town is the Austro-Hungarian Empire and its military regiments, specifically the no. 17 Frontier Regiment of Năsăud, later changed to the no.50 Infantry Line Regiment. In the transformation process all the profits gained by the military regiment were constituted into the Frontier Regiment Funds, which would serve the purpose of helping and investing in different cultural and urban activities (Vlașin, 2014). The aforementioned military organization and its activities involving the town and its surroundings represent the first bricks being laid at the modern foundation of the urban development. With a calculated approach based on practicality and inventory, the regiment started developing the first settlements around the natural mineral water springs, the evolution of these developments being presented very clearly through a set of maps representing the town and its territory. (Fig.2). 

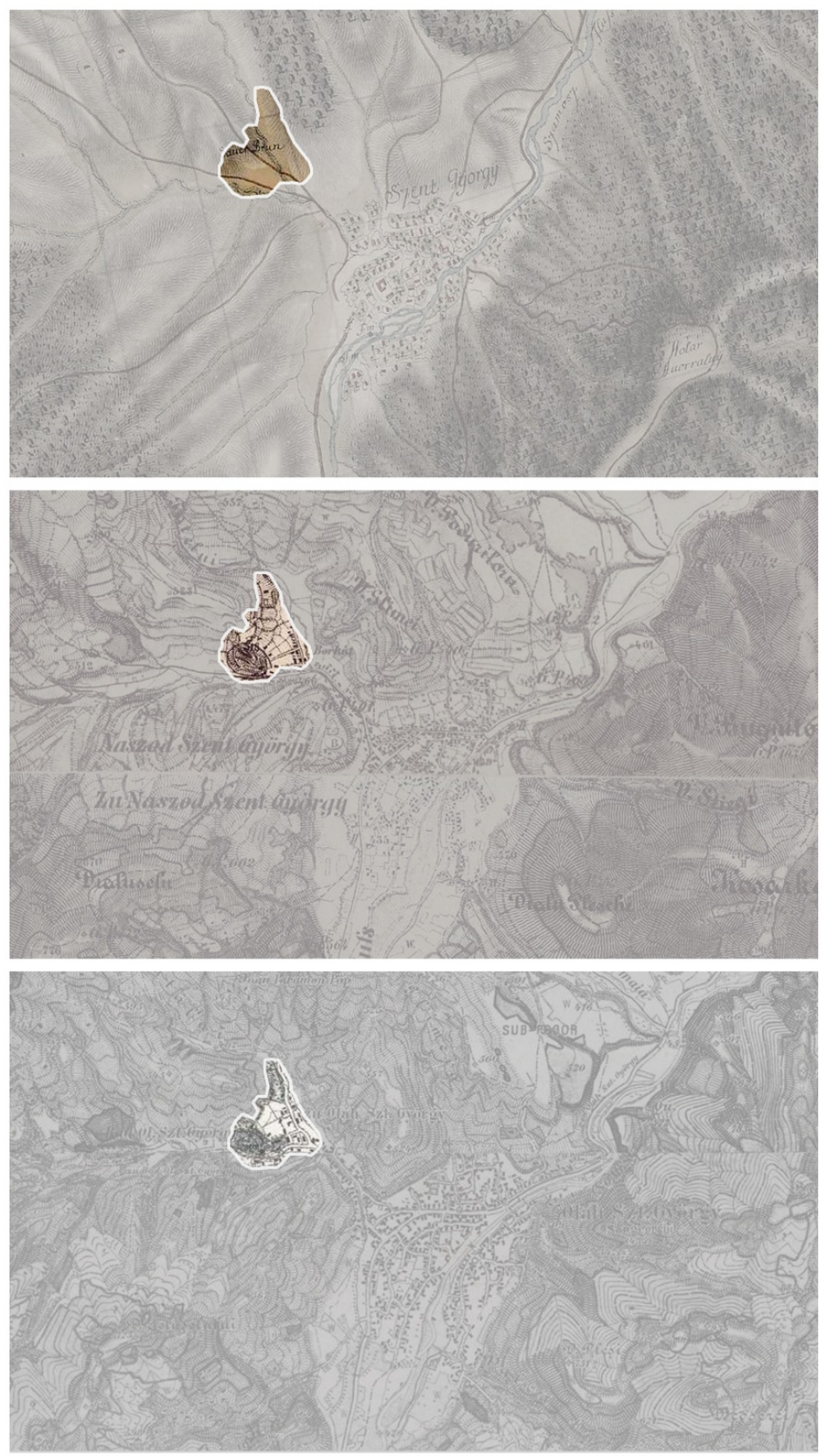

Fig. 2. - Maps depicting the clear evolution of the developments (in the north-western part of the town) under the influence of the Frontier Regiment; 1763-1787 (top), 1806-1869 (centre), 1869-1887 (bottom). Source: http://mapire.eu/en/ 
The first picture shows the map of the town before any implication of the military regiment, the second and third pictures presenting evident improvements in the north-western part of the town, where the mineral springs reside. Historical documents dating from 1860 to 1895 provide insight into the dialogue between the locals and the administration of the frontier regiment funds, the latter lending monetary support to the community and local authorities for the creation of urban developments near the natural springs and also sustaining the appearance of the first solid material church built in the town ("The administration of the Frontier Regiment Funds", 1860-1895).

An important year in the history of the Romanian spa-towns is 1868, when the Society of Hydrology was created in Bucharest at the initiative of Carol Davila. The organization had the purpose of researching and validating the importance of the spa-towns situated within the Romanian territory (Voinea \& Baran, 2008). This marked an important point in the national perception and attitude towards the usage of natural mineral waters - the introduction of the medical perspective to a relatively unorganized field of activities (Hajdu, 2012). However, a lack of clear set laws undermined the possibilities of the medical organization.

One of the first medically driven approaches towards the natural springs of Sângeorz-Băi was Dr. A.P. Alexi's "Die St.-Georger Säuerlinge im Nordosten Siebenbürgens", which in 1892 described the waters and its qualities as occupying one of the first places in Europe regarding its value (Alexi, 1892). It is no surprise that the spa-town sees itself taken into administration by a medically governed association, by the name of The Hebe ${ }^{5}$ Society. While in the hands of the predominantly medical administrative society, the spa-town knew its historical prime. Documents suggest that the association had two periods of interference in the development of the town, once between the years 1879 and 1902, and the second - and most important time, concerning its legacy, between 1911 and 1928 ("Climatic mineral baths in Sîngeorzul-Român", n.d.). In the periods between these years, the spa-town was administrated by the local authorities. A medical prospect dating back to 1904 presents the development, then known as St. Giorgiul-Român, as a flourishing establishment with mineral waters superior to those of Vichy, Grand-Ville and other better-known western towns of the same profile ("Prospect of the 'Hebe' Alkaline Baths from Sângeorgiul-Român", 1904). The constant comparisons with Europe's more popular destinations exemplify the cultural relevance that these types of urban establishments pursue. The same brochure offers insight towards some of the first dwellings constructed on the village territory (Fig. 3), the images representing the bourgeois atmosphere

\footnotetext{
${ }^{5}$ In ancient Greek mythology, Hebe - daughter of Zeus - was the goddess of youth, cupbearer for the gods and goddesses of Mount Olympus.
} 
of the old village and its mineral springs ("Prospect of the 'Hebe' Alkaline Baths from Sângeorgiul-Român", 1904, p.8). The public's interest towards music, fine dining and organized trips throughout the neighbouring surroundings that the brochure exposes, along with the medical facilities that it presents, confirm the impact that the Hebe Society had on the village. Although not a political group itself, the society worked with the local authorities for the benefit of the village. The contract signed between the two parts feature agreements such as: the right of demanding plots that the society may use for constructing leisure facilities, the obligation for the Hebe group to invest in buildings and the park, and the obligation to keep a constant medical presence in the spa-town. The contract also states that the building materials and work force that will be needed will be provided by the town officials ("Lease Contract between the Society and the Town", 1922). These fragments of insight regarding medical organization-local administration relationships exemplify the manner in which political representatives of the establishments entrusted in the aforementioned societies, underlining the role of the administrative units as a supervising one.

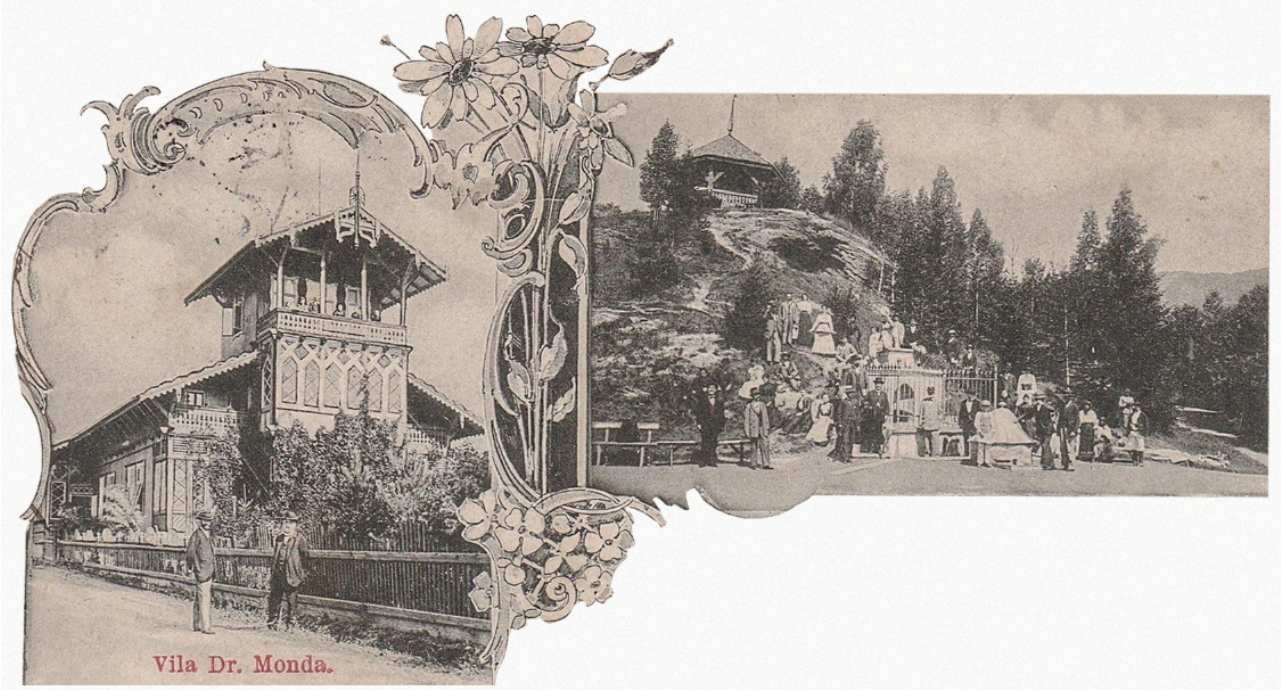

Fig. 3. - Images representing some of the first dwellings constructed in SângeorzBăi's territory, offering insight into the atmosphere present at those times.

Source: "Prospect al Băilor Alcalino-Muratice 'Hebe' din Sângeorgiul-Român, Comitatu Bistrița-Năsăud (Transilvania)" ["Prospect of the 'Hebe' Alkaline Baths from Sângeorgiul-Român, Bistrița-Năsăud County (Transylvania)”] (1904), (Tipografia G.Matheiu, Bistrița), p. 8. 
As stated before, the medical presence is one of high importance, in the field of the old spa-towns. The medics would keep note of all their research and publish it every year so that the conclusions could serve for future purposes. Along with other intellectual visitors, the medics would organize courses on different subjects that the tourists could attend, contributing to the general atmosphere of cultural exchange that the old village embodied. An old orientation guide from 1914 mentions - besides the obvious medical facilities - a rich library, a piano room and a tennis court, while a cultural event invitation from the same year details a program of diverse theatrical representations (Fig. 4). The latter also mentions that students will have a reduced entry fee and that the financial gain of the event will be directed towards the town's library ("Invitation for a Theatrical and Musical Evening Event", 1914). These historical documents, among many others, depict a period of social and cultural loans that the Romanian people were drawn on. The main theme of this period in the history of spa-towns was one of a continuous process of absorption and imitation of the social, cultural and artistic values of the more advanced western European countries. A key part in this endeavour is also represented by the times in which these events take place, the union of Transylvania to Romania taking place in 1918.6 From this moment on, from a tourist perspective, knowing and experiencing your own country becomes as important as exploring the Occident (Hajdu, 2012). Sângeorz-Băi became an even more popular destination following the expansion of the railroad system between 1909 and 1912 (Sohorca, 1986) ${ }^{7}$, the neighbouring village of Ilva Mică becoming an important railway station and junction, placed on a route connecting different regions of the now unified country. The rising number of tourists following these changes can easily be seen in a visitor tableau that depicts the number and nationality of the tourists, as well as statistics based on gender or other criteria ("Visitors Tableau of the 'Hebe' Baths of Sîngeorz-Băi", 1927). A large part in this period of flourishing is played by the tandem between local authorities and the before mentioned administration societies, the capitalistic manner in which town officials entrust in the societies mirroring the entire modernization process. For Sângeorz-Băi, this period of collaboration ended in 1928, when the contract between the authorities and the organization is terminated, the Hebe Society citing in their liquidation papers that the main reason behind the disagreement resides in the town officials' plans for a larger scale development of the establishment ("Liquidation notice regarding the 'Hebe' Society", 1928). In the case of this

\footnotetext{
6 The Union of Transylvania with Romania was declared on the $1^{\text {st }}$ of December 1918.

${ }^{7}$ After the edification of the Ilva Mică - Vatra Dornei railroad, Sângeorz-Băi found itself on one of the most important train routes of the newly formed state, fact that contributed to the rise in popularity that the spa-town gained.
} 
particular spa-town, it appears that the relation between the two entities was one of relative success, the pair augmenting each other in the common search for emergence. However, not all other Romanian establishments had the same fate.

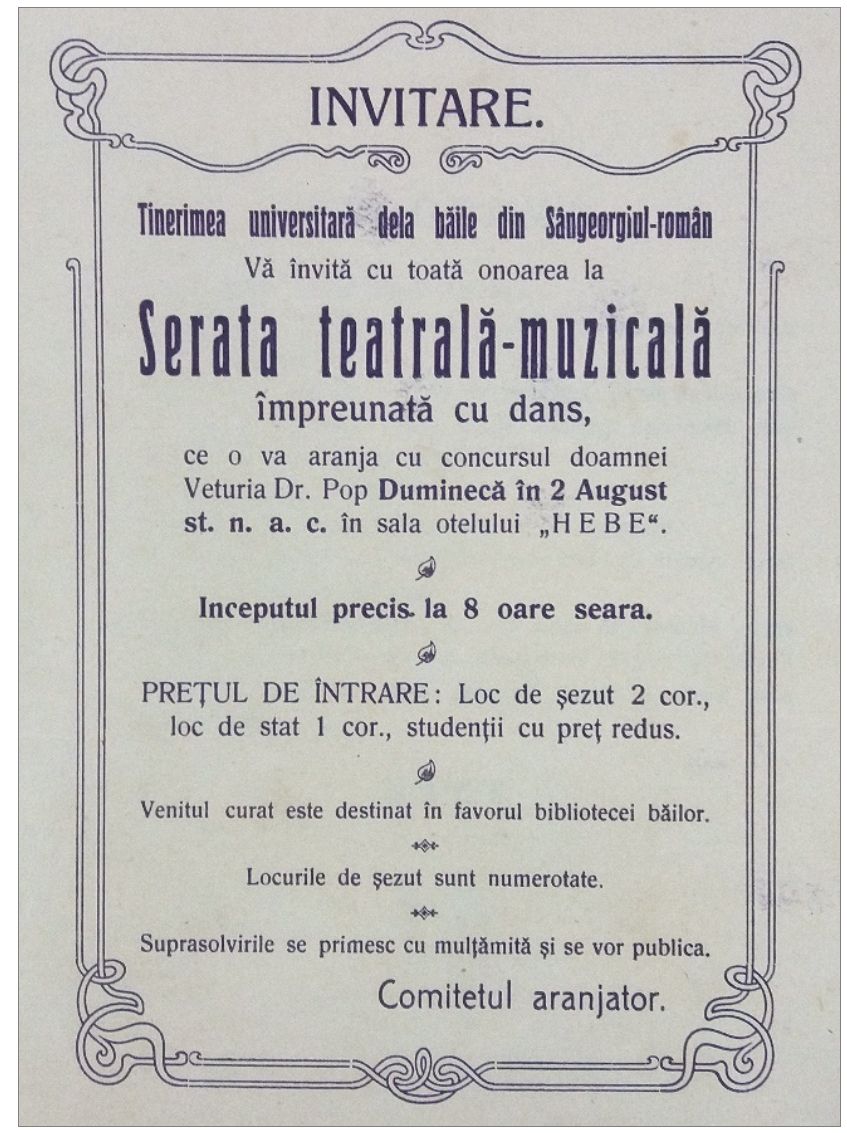

Fig. 4. - Cultural event invitation from the year of 1914, depicting the cultural activities that the Spa-Town visitors and locals could attend to.

Source: Arhivele Naționale, Serviciul Județean Bistrița-Năsăud, "Societatea

Hebe 1882-1939" ["The Hebe Society 1882-1839”].

\section{A search for order}

One of the means through which the aforementioned Society of Hydrology was promoting and raising awareness regarding the situation of the Romanian spa-towns was its magazine, "Curierul Băilor" - a monthly paper published by 
the organization in order to popularize the spa-town tourism field in the public eye. The magazine served as an information platform as well as a place where people involved in the field could exchange ideas and express concerns. Throughout the history of the medical and political contingent regarding the mineral water based urban developments, there have been a lot of tensed situations, mainly caused by the lack of legislative support that the medical societies have received. In an issue of October 1929, an article entitled "Another communal bad deed" mentions a few situations in which the collaboration between local authorities and medical societies did not work in a positive manner. The feature is very critical concerning the interest that local administrations have towards sustaining and protecting the establishments in their territory. While the medical societies use the raised funds in order to reinvest in the well-being of the spas, the local authorities are being criticized for imposing a large number of taxes on the tourists and the medical organizations without having the intention of reinvesting the tax money in the spa-establishments. Episodes consisting in intentions of totally separating the spa-establishments from the spa-town itself in the case of Tușnad because of poor political support, or instances of over-taxing nearly bringing the medical organization in charge to an end in the case of Busteni, describe a tense situation in the relationship between the two types of entities ("Another communal bad deed", 1929). Proving once again the manner in which this field is focused on keeping up with the western trends, articles in which comparisons of the national concerns within the domain are made with those from England or France are also present. Because of the fact that a large number of spa-town visitors are workers, this specific type of therapy being one that resolves a lot of occupational diseases, a balneotherapy social assistance program was introduced. Although far behind in many respects concerning the field, it is shown that with regard to the aforementioned social program, Romania was one of the leading figures, ahead of, for example, its English counterpart ("Spa social assistance", 1929), with a total of 15.747 .602 lei spent in 1927 alone on balneotherapy welfare beneficiaries. The Society of Hydrology also looked with admiration towards their French peers, being impressed by the serious fashion in which they conduct the program of mineral waters protection, with strict laws regarding the fraud and disloyal competition involving artificially mineralized waters ("Mineral water protection in France", 1929).

A more critical approach towards Romania's tourism infrastructure is that penned by the internationally renowned biologist, speleologist and explorer, Emil Racoviță. The once president of the Romanian Academy for Science and Culture addresses the state in which the country's tourism segment presents itself and the need for creating a National Tourism Office. The proposed 
organization would have served as a guardian for the entire field, with a high emphasis on the importance of spa-towns. Its missions would include guidance and support towards local authorities regarding transport infrastructure and tourist attraction conservation, awareness spreading involving the facilities and beauties of the Romanian spa-towns, and the protection of the natural and built heritage that these establishments possess. The scientist was concerned with the way tourism was treated in Romania, placing the country years behind other better organized European nations, and stating that it is the state's duty to facilitate the evolution of its tourism branch (Racoviță, 1929).

The fourth decade of the $20^{\text {th }}$ century proved to be a problematic one for both Romania's spa-towns and its entire tourism scope, the general atmosphere of the subject matter being one of economic issues, poor infrastructure and a bothering lack of helpful legislation ("Program of the Congress and Autumn General Meeting", 1930). Albeit the rather bleak manner in which the field presented itself, a somewhat hopeful disposition emerges on the 26 of March 1936, in the form of Law No. 569. Published by the Parliament under the rule of King Carol II of Romania, the law presented special dispositions regarding the country's spa-towns. Besides several new economic advantages and clearer development regulations, a set of two specifications within the law were particularly interesting. The law specified that the mayor of a spa-town should possess an academic title ("The No.569 Law from the 26th of March, 1936", article 111) and that the parliamentarian mandate is incompatible with that of a mayor, with only two exceptions in the form of the representatives of the capital city Bucharest and those of spa-towns ("The No.569 Law from the 26th of March, 1936", article 114). These dispositions depict the high regard in which these establishments were held, and the general consensus that the sojourn sphere was one of great importance for the entire nation, echoing the statements made by the aforementioned members of the scientific and cultural communities. Accepting spa-towns as both a health and leisure necessity, but also as a cultural nest where ideas can be discussed and inserted into the Romanian society as a whole, was a big step needed in the evolution of this type of developments. Synchronization with the western counterparts never seemed closer than in this moment of legal recognition, when spa-town establishments were placed on the very same page with the nation's capital city. Was this the moment that the Society of Hydrology was longing for? Did Racoviță's plead for the state's implication come to fruition? In a very pragmatic point of view, yes, the search for order and normality was, at least on paper, starting to find its goals. Spatowns, however, with Sângeorz-Băi not proving itself to be an exception, were not yet facing a sudden twist of destiny under the charm of a great political gesture, but the same old steady stagnation with rare improvements that they 
found themselves into since the end of the third decade of the $20^{\text {th }}$ century. Other changes due to political reasons, nevertheless, were to follow shortly after.

\section{A search for modernity}

The years that went by between 1936 and 1947 were those of a time of change in the realm of spa-towns, especially in the case of the northwestern Transylvanian ones, which faced a political and geographical relocation in the aftermath of the Vienna Dictate of 1940, which stated that half of the region would be submitted to Hungary. Albeit a period of tension, there are no documents that describe major changes in the field of spa-town establishments, especially in the case of Sângeorz-Băi. Besides a strained atmosphere from 1940 to 1944 and a world war that would definitely affect the town, the local authorities also faced a fire that destroyed the town hall and also a large part of the town's documents ("Big Fire in Sângeorz-Băi", 1939), hence the lack of historical information dating from this period.

Probably the most polarizing changes the field of spa-towns has dealt with are those by the hands of the communist regime. Active from 1947 to 1989, the totalitarian regime - in its many forms - would leave permanent marks in the history of the entire country. Sângeorz-Băi, the entire realm of sojourn related towns, and the whole nation, were entering a new phase influenced by the Soviet Union and its political views.

It is not the subject of this paper to analyse the entire sum of effects that the communist regime's influence had on Romania and its people. However, it is important to the subject to mention one of the party's many debatable efforts, the nationalization law. Adopted on the $11^{\text {th }}$ of June 1948, the law was synonymous with a change in the country's economic policy, from a capitalistic direction to a centralized state one. The new legislative rule stated that the totality of the territory's resources that do not belong to the state shall be nationalized, thus becoming its property. Although on paper the process had a fair share of compensation regulations, the whole affair had more of a confiscation undertone. Mineral waters, as one of the territory's resources, were no exception to the operation. The entirety of the spa-town realm, with both its natural springs and its built infrastructure were now in the hands of the communist state. A glimpse on a document from April 1949 mirrors the way in which this process unravelled for the case study spa-town. The document is written in the form of a solicitation towards the local authorities of SângeorzBăi, demanding with utmost importance and urgency a description of the situation regarding the town's establishments and villas. The response, which 
carefully describes the name, location, capacity and ownership of the structures, offers insight into the number of the edifices still existing during that period, most of them being lost at present times. A most interesting fact about the list, however, consists in the names of the establishments. Besides a villa and a hotel under the familiar name of Hebe, the names of important medics from the earlier times in the town's history are also present on the list, in the likes of housings belonging to Dr. Scridon or Dr. Monda, both important names in the Hebe Society. As all the tourist destinations were prepared for the country's people, all these locations became favourite vacation places for several work syndicates, in the case of Sângeorz-Băi, the state railway carrier, CFR. However, problematic the process was, the years to come were ones of modernization, with electricity and several other infrastructure improvements being developed, in the likes of accessibility, bathing conditions and mineral water extraction technology improvements.

By 1957, Sângeorz-Băi had a modern water bottling process, exporting its natural goods towards several Romanian towns and even to other European countries ("Agreement between the Hebe Society and 'Generala' S.A. regarding mineral water exportation to England and the U.S.", 1926). In 1960, the town became a regional subordinate city, thus qualifying as eligible for large investments. Little more than 10 years later, the city would inaugurate two modern hotels, one that would later be known as the new Hebe Hotel, with a capacity of nine hundred sleeping places, and another one, now known as "Someșul"- taking its name from the river that passes through the town, that could host another six hundred people. The new structures were built in a modern fashion, by renowned architects from the Regional Construction Trust from Cluj. The new establishments still present today was built with the features of the international style, bearing no resemblance to the old buildings of the historical town (Fig. 5). However, this was not an impediment to the popularity of Sângeorz-Băi as a tourist destination, the city quickly becoming a popular vacation spot for Romania's working class. The natural scenery, the mineral waters and the remaining somewhat rural atmosphere still had their charm. All these, augmented by the presence of modern conditions took the city to an entire new level of appreciation, shaping what would become the spa-town's golden years. However, from an architectural point of view, the search for modernity would mark the beginning of the end for the historical establishments, the new prevailing against the old. 

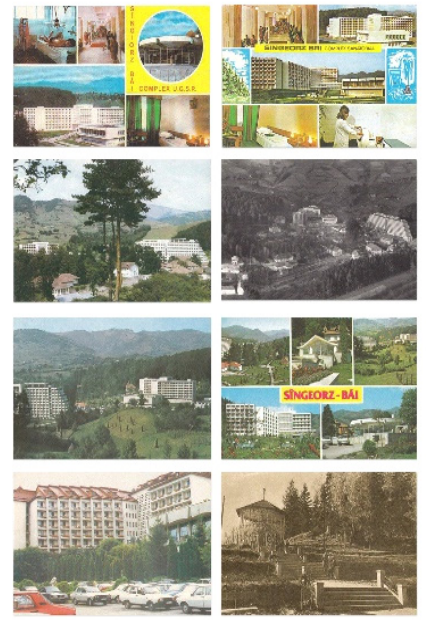
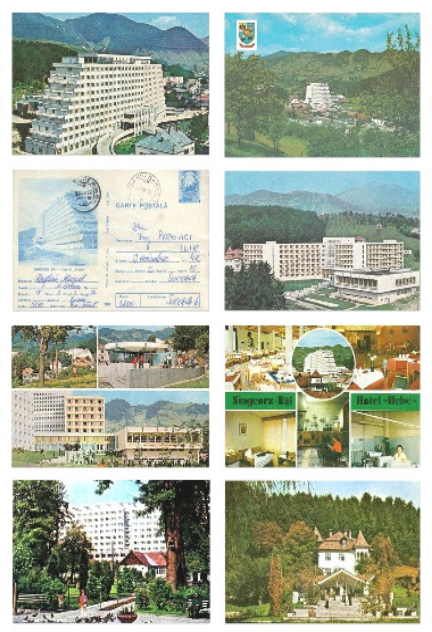
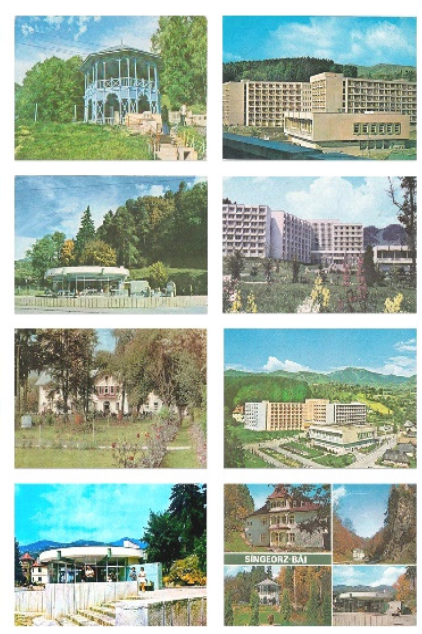

Fig. 5. - Selection of postcards from Sângeorz-Băi, from its socialist embodiment. Source: author.

\section{A search for belonging}

As Romania's socialist past is a fairly recent one, it is no surprise that the current state of Sângeorz-Băi is highly resembling to its communist apparel. The degree in which the establishment has not changed since 19898 is striking. Besides small insignificant additions to its built inventory, the town evokes the same atmosphere that it presented in its communist phase. However, this does not mean that the city is still flourishing with visitors. The once fully booked hotel rooms and villas became more and more empty as the years went by, leaving the once thriving urban development a mere memory from the past. Romania's journey back to capitalism proved to be a rather difficult one, the majority of the present day spa-town difficulties being rooted in the way that the nationalized properties were being returned to their original owners or in the manner in which the aforementioned properties were privatized. A lack of investments and resources paved the way to a slow but steady decay, either by the faults of companies that show little to no interest in restoring the establishments to their former effervescence (Cotuțiu, 2005), or because of the financial difficulties the new owners face.

The time span between 1990 and the present day can be seen as the most harmful period that the historical buildings of Sângeorz-Băi have faced. One could argue that the socialist years, defined by a lack of interest towards

\footnotetext{
8 The year of the Romanian Revolution marks the end of 42 year of communist rule in Romania.
} 
heritage were the true nail in the coffin for the remaining structures from the old establishment, but at least during that period of time the buildings were inhabited and held under a certain amount of supervision. The dawn of capitalism revealed a broken country, and in the case of Sângeorz-Băi, a broken spa-town. The historical edifices that resisted through the communist regime were now pawns in a long series of property games, affairs that would see them in the hands of either uninterested owners, or in the possession of people and companies unfit to handle them with proper care.

Villa 13, for example, with its ownership permanently disputed between local authorities and other different entities found itself becoming a restaurant, and later a night club, with its once fully booked sleeping rooms being used for different types of offices and business venues. Vila 1, the only historical monument presents in Sângeorz-Băi (Fig. 6), saw itself exchange ownership between several state institutions, such as the Romanian Intelligence Service or the County Council of Bistrița-Năsăud (Gheorghe, 2016), the constant property swaps participating directly in its present day decadence, with the building finding itself on the brink of destruction.
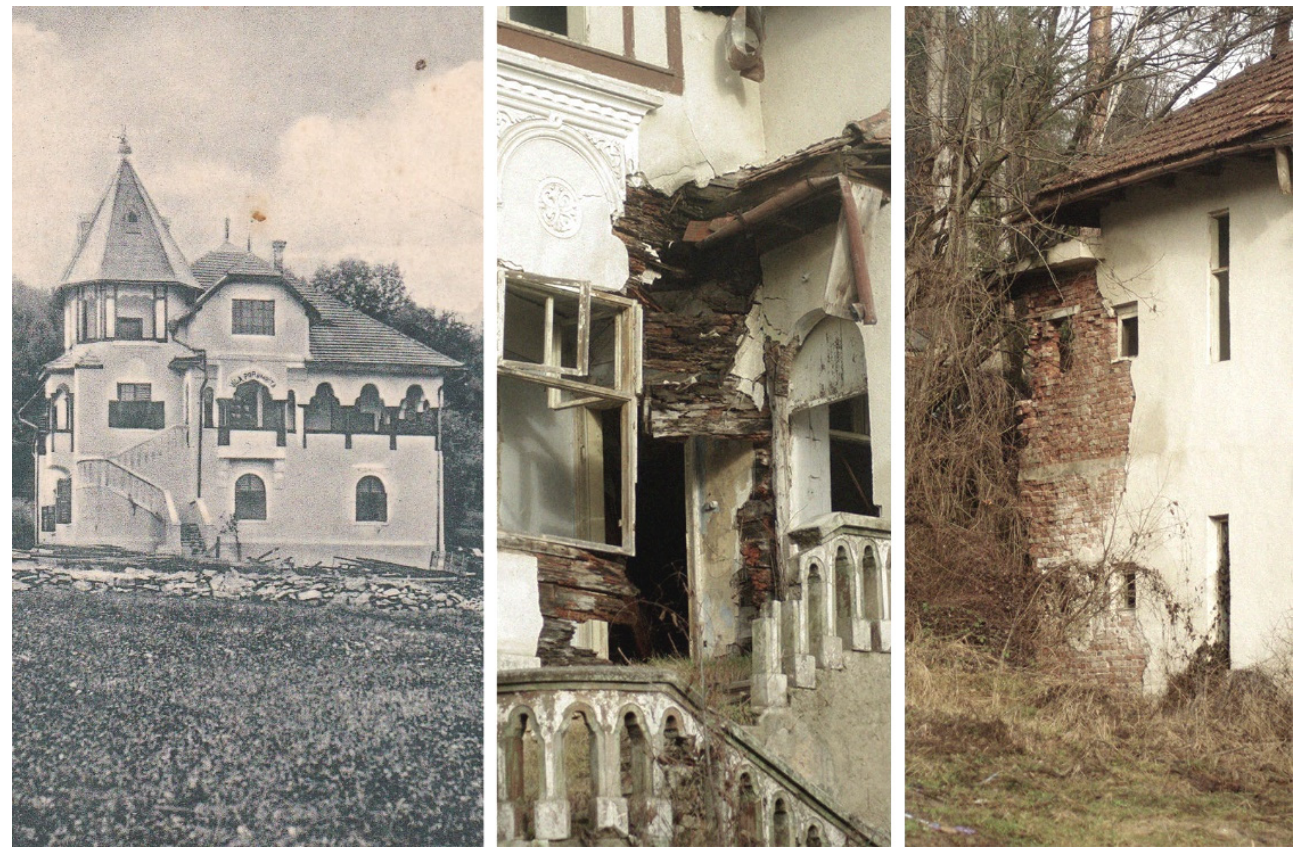

Fig. 6. - The past and present of Vila 1 (or Vila Porumbița), a historical monument plagued by neglect. On the left, the building upon its inauguration, on the right and centre, its state in the summer of 2018. Source: author. 
The old Villa Mia, now Villa Sindi (Fig. 7), although retaining its former sojourn function under the ownership of a schooling syndicate from the Romanian town of Iași, is clearly an example on how not to refurbish a historical building, suffering several questionable functional and aesthetical changes. Other architectural objects, such as the Dr. Ciuta Sanitarium, were demolished (Fig. 8) in the aftermath of long and agonizing judicial disputes between property claimants.
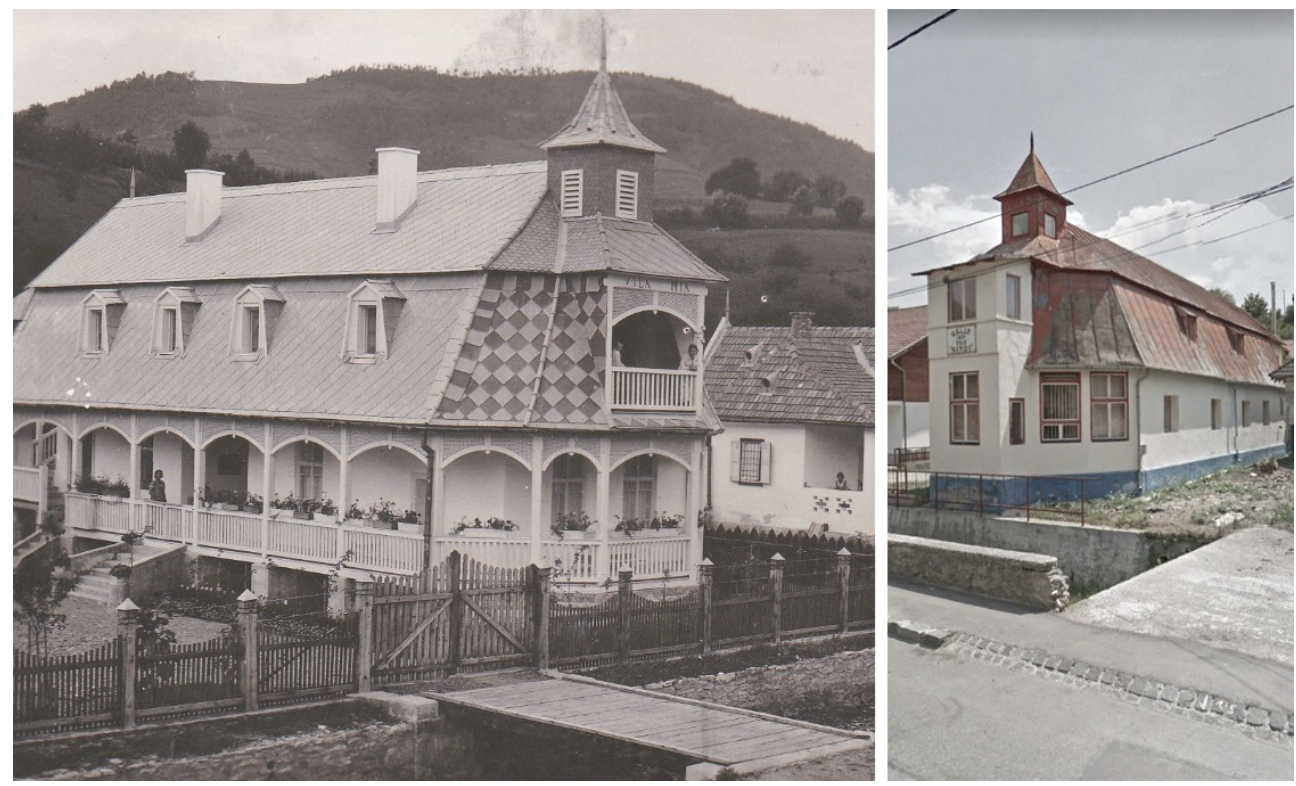

Fig. 7. - The past and present of Vila Sindi, a historical building plagued by inappropriate interventions. On the left, the building at the beginning of the $20^{\text {th }}$ century, on the right, its state in the summer of 2018. Source: author.

To make things worse, even the socialist structures - built less than fifty years ago - present themselves in a decaying manner, the lack of interest and investments from the companies in charge of the Hebe and Someșul hotels being synonymous with a low level of interest from possible tourists. Under the circumstances, Sângeorz-Băi and its entire sojourn related components are facing a time of uncertainty, as the fast pace of the new millennium proves to have no patience with the city's most disputed yet unwanted and misunderstood architectural heritage. 
These are the years defined by the spa-town's search for belonging, which find it in a most awkward and difficult position, on the brink of losing its already shattered identity.

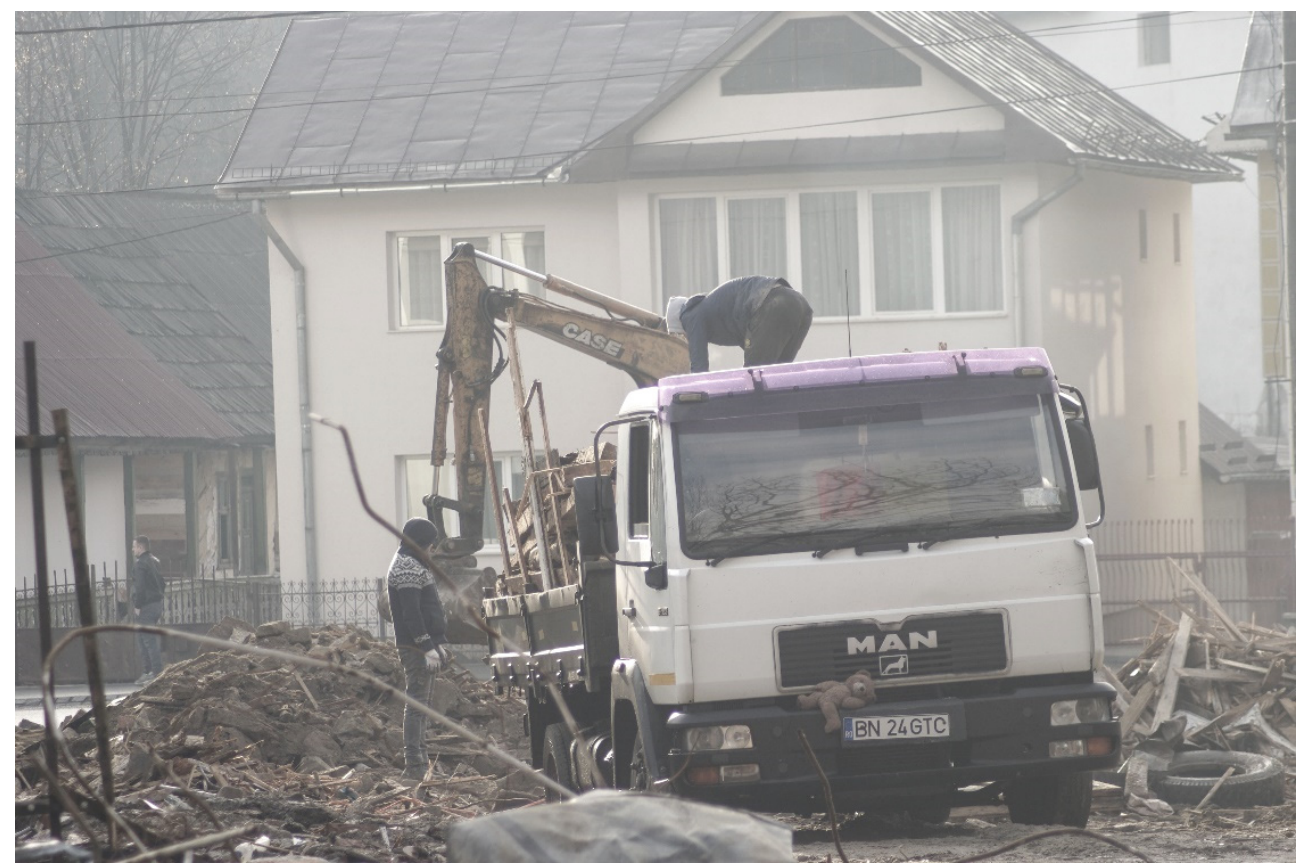

Fig. 8. - The demolition of the Dr. Ciuta Sanatorium in the summer of 2018, after years of disputes regarding its ownership. Source: author.

\section{Conclusions - or a plea for search}

One thing is certain, although being a natural gift that few territories are lucky to have received, mineral waters do not have enough power to keep the establishment alive by themselves. There has always been a motor behind every period of success that the town of Sângeorz-Băi has ever had, the natural springs representing the oil that fuels and keeps the motor working properly. The catalyst of the establishment's prosperity has taken many forms, from the likes of the Frontier Regiment, to those of the medical organizations and even the communist regime, thus there has always been a driving force behind the development's wellbeing. Political origins are not a sine qua non quality for the manifestation of these incentive entities, the only imperative 
trait for these individuals or groups being a desire to do better. This should either refer to the improvement of a way in which things are developing currently or to a responsible approach towards mending the realizations of the preceding incentives (Fig. 9). The nod to John Ruskin's works at the beginning of the article has not been unintentional, his works being advocates of how practical action and understanding - that it is the duty of the privileged, or in this case those in a position where they have the possibility to act, to make their world a more beautiful and self-aware place - an attitude that in the case of Sângeorz-Băi is somewhat present, but in a form that is polluted by an unclear strategy and a fascination for immediate financial gain.
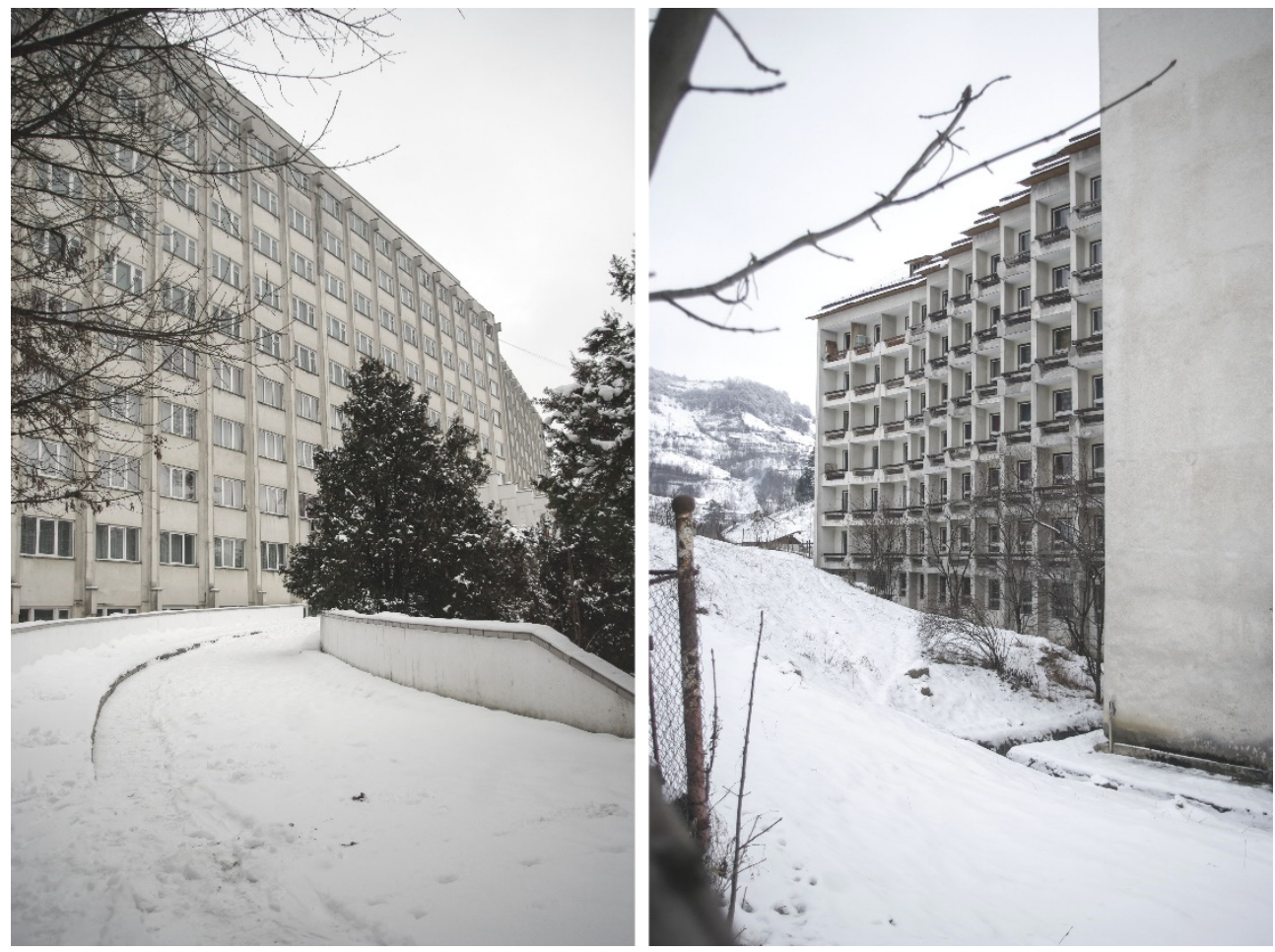

Fig. 9. - The current state of the hotels built during the socialist period. Even though they can be regarded an architectural counterpoint to the Belle-Époque spa-town's built repertoire, these buildings should imperatively be a part of any strategy concerning the spa-towns revival, being an important part of its heritage. Source: author. 
Essentially, the affairs of a city, spa-town or not, must be conducted with wisdom and an ability to make the right decision in a majority of circumstances. In the case of Sângeorz-Băi, the demolition of one of the last standing villas from the historical sojourn village, under its fatidic name of Villa 13, represents an agonizing dilemma. The edifice was a witness of time, a fragment of history that was transmitted from generation to generation, passed from elders to children, connecting entities from different periods and of different values. However, it was also clearly affected by at least thirty years of neglect and indifference, mirroring, in a way, the entire recent destiny of spa-towns.

The entire affair can be very well seen as a lesson about time and its relativity, as apparently thirty years of carelessness weigh more than an entire century of flourishing. From a very pragmatic point of view, yes, the decaying villa may have represented a danger towards children passing-by, but surely some physical site protection barriers in the wait for an intelligent non-destructive strategy could have been a more reasonable approach than depriving the spatown's youth of their past - especially in the European Year of Cultural Heritage.

Undoubtedly, Villa 13's fate is just a herald of the entire country's historical spa-town predicament. The building's demise cannot even be pinpointed to the present town's local authorities, they themselves merely inheriting a longbefore rolling snowball. A plea, however, must be made - towards them, towards their future peers, towards anybody with a will to make things better - a plea for a continuous search on how to act with one of the country's most precious yet unexploited natural gifts, a plea for curiosity and research involving past behaviours that have helped these establishments flourish - a plea for wisdom and responsibility.

The town's historical journey was one defined by constant searches, so it comes as no surprise that in present times Sângeorz-Băi and the majority of the Romanian spa-towns are in a state of disarray, as their pursuit of meaning and belonging proves to be a rather difficult endeavour. The present paper's purpose was not only to narrate the trials and tribulations that the case study town has faced, but rather to identify the incentives behind its turning points, and learn from past experiences - with the hopes that the information retrieved would prove useful for all the parties involved in the current state of the spatown realm. One must thus remember the importance of the search of beauty and understand the fact that natural scenery and its gifts must be completed by a calculated approach towards the architectural insertions present or desired in its area. The search of emergence must be patient, yet determined, as it takes carefully crafted strategies and combined efforts from both local administrations and field experts to understand and try to resolve the current state in which these establishments reside, thus making cooperation a key element 
of the reviving process, along with a search for order - through which these efforts can be legislated. The prospects that the Romanian spa-towns have for the future must also be carefully tied to a search and understanding of modernity, as the word's meaning often changes - not in the sense of embracing the new instead of the old, but rather in having a modern, open minded perspective on the entire historical spa-town subject and using the existing heritage as a cornerstone of future developments, avoiding the loss of identity that the aforementioned establishments would otherwise face and ending the search for belonging that places the entire Romanian spa-town spectrum in an architectural and historical limbo.

\section{REFERENCES}

1. „Acord între Societatea Hebe și 'Generala' S.A. de Comerț și Industrie pentru a exporta apă în Anglia și S.U.A." ["Agreement between the Hebe Society and 'Generala' S.A. regarding mineral water exportation to England and the U.S."] (1926), Arhivele Naționale, Serviciul Județean Bistrița-Năsăud, f. 00143, „Societatea Hebe 1882-1939".

2. „Administrația Fondurilor Grănicerești Năsăudene” [“The administration of the Frontier Regiment Funds"] (1860-1895), Arhivele Naționale, Serviciul Județean Bistrița-Năsăud, f.2757, ff. 1-114.

3. Alexi, A.P. (1892), "Die St.-Georger Säuerlinge im Nordosten Siebenbürgens und die Flora auf dem Gebiete derselben", Druck Von Josef Drotleff, Hermannstadt, pp. 1-11.

4. „Asistența socială balneară” ["Spa social assitance”] (1929), in Curierul Băilor, Stațiunilor Climatice și turismului, Societatea de Hidrologie și Climatologie medicale, nr. 15, 30 October 1929, București, p.172.

5. „Aviz de lichidare a Societății 'Hebe”" [“Liquidation notice regarding the 'Hebe' Society"] (1928), Arhivele Naționale, Serviciul Județean Bistrița-Năsăud, f. 00143, „Societatea Hebe 1882-1939”.

6. „Băi minerale climatice în Sîngeorzul-Român (Oláhszentgyörgy)” [“Climatic mineral baths in Sîngeorzul-Român"] (n.d.), Tipografia G. Matheiu, Bistrița.

7. „Contract de arendare între comună și Societatea Hebe” ["Lease Contract between the Society and the Town"] (1922), Arhivele Naționale, Serviciul Județean BistrițaNăsăud, f. 00143, “Societatea Hebe 1882-1939", pp.1-8.

8. Cotuțiu, Liviu (2005), „Cine este acționar majoritar la Hebe S.A.?”, Gazeta de Bistrița, Bistrița, 20 iunie 2005,

https://www.hotnews.ro/stiri-presa_regionala_arhiva-1734891-cine-este-actionarmajoritar-hebe.htm - last accessed on March 1, 2019, 18:00. 
9. „Foc mare la Sângeorz-Băi” [“Big fire in Sângeorz-Băi”] (1939), în Unirea Poporului, Blaj, nr. 35, 27 August 1939, p.2.

10. Gheorghe, Eugen (2016), „Ce se va întâmpla cu Vila nr. 1 din Sîngeorz-Băi, monument istoric", Timp Online, Bistrița, 23 decembrie 2016, https://timponline.ro/ce-se-va-intampla-cu-vila-nr-1-din-singeorz-bai-monumentistoric/ - last accessed on March 1, 2019, 18:00.

11. Hajdu, Ada (2012), „Arhitectura de Vilegiatură în România Modernă”, teză de doctorat, Universitatea Națională de Arte, București, pp.14-50.

12. „Invitare Serata Teatrală-Muzicală” [“Invitation for a Theatrical and Musical Evening Event"], (1914), Arhivele Naționale, Serviciul Județean Bistrița-Năsăud, f. 00143, "Societatea Hebe 1882-1939", (Tip. G. Matheiu, Bistrița).

13. „Încă o faptă rea comunală" ["Another communal bad deed”] (1929), în Curierul Băilor, Stațiunilor Climatice și turismului, Societatea de Hidrologie și Climatologie medicale, nr. 15, 30 Octombrie 1929, București, p.179.

14. Legea nr. 569 din 26 Martie 1936 [The No. 569 Law from the 26 $6^{\text {th }}$ of March 1936] (1936), Art. 111-114.

15. MacCannell, Dean (1999), "The Tourist: A New Theory of the Leisure Class", University of California Press, Berkeley, pp.1-42.

16. „Prospect al Băilor Alcalino-Muratice 'Hebe' din Sângeorgiul-Român, Comitatu Bistrița-Năsăud (Transilvania)" ["Prospect of the 'Hebe' Alkaline Baths from Sângeorgiul-Român, Bistrița-Năsăud County, (Transylvania)”] (1904), Tipografia G.Matheiu, Bistrița.

17. „Protecțiunea apelor minerale în Franța” ["Mineral water protection in France”] (1929), în Curierul Băilor, Stațiunilor Climatice și turismului, Societatea de Hidrologie și Climatologie medicale, nr. 15, 30 Octombrie 1929, București, p.174.

18. Racoviță, Emil (1929), „Oficiul Național Turistic - Necesitatea Organizărei lui în România" ["The National Touristic Office and the Need for its Creation in Romania"], în Curierul Băilor, Stațiunilor Climatice și turismului, Societatea de Hidrologie și Climatologie medicale, nr. 15, 30 Octombrie 1929, București, pp.173-174.

19. Ruskin, John (1849), "The seven lamps of Architecture", John Wiley, 161 Broadway, New York, p.9.

20. Sohorca, Iustin (1986), „Povestea Comunei Sîngeorz-Băi”, Cercul Plaiuri Năsăudene și Bistrițene, Cluj-Napoca, pp.17-53.

21. „Tabloul vizitatorilor Băilor 'Hebe' din Sîngeorz-Băi” [Visitors Tableau of the 'Hebe' Baths of Sîngeorz-Băi] (1927), Arhivele Naționale, Serviciul Județean BistrițaNăsăud, f. 00143, "Societatea Hebe 1882-1939".

22. Voinea, Alexandra; Baran, Dana (2008), „0 incursiune în istoria întreținerii sănătății prin apă în România”, Jurnal Medical Brașovean, Brașov, pp.172-176.

23. Vlașin, Cornelia-Nicoleta (2014), „Istoricul Fondurilor Grănicerești 1851-1947”, PhD diss., Institutul de Istorie „George Barițiu” al Academiei Române, Cluj-Napoca, pp.6-7.

24. Vlădică, Mircea (2003), „Sîngeorz-Băi, Veche Vatră de Credință și Cultură Românească”, Editura Napoca Star, Cluj, p.253. 